\title{
Lipolytic Activity of Potential Probiotic Enterococci and Additive Staphylococci
}

\author{
M. SIMONOVÁ ${ }^{1}$, K. SIROTEK ${ }^{2}$, M. MAROUNEK ${ }^{2}$, A. LAUKOVÁ ${ }^{1}$ \\ ${ }^{1}$ Institute of Animal Physiology, Slovak Academy of Sciences, Košice, Slovakia \\ ${ }^{2}$ Institute of Animal Physiology and Genetics, Academy of Sciences of the Czech Republic, \\ Prague, Czech Republic \\ Received November 5, 2007 \\ Accepted July 7, 2008
}

\begin{abstract}
Simonová M., K. Sirotek, M. Marounek, A. Lauková: Lipolytic Activity of Potential Probiotic Enterococci and Additive Staphylococci. Acta Vet. Brno 2008, 77: 575-580.

The ability to produce lipolytic enzymes by enterococci and staphylococci isolated from rabbit faeces and traditional Slovak sausages was examined. Seven strains (3 by genopypization allotted to the species Enterococcus faecium and 1 Enterococcus species of rabbit origin, 2 rabbit staphylococci and 1 Staphylococcus xylosus SX SO1/1M/1'/2 strain - sausage isolate) were lipolytic activity free, whereas lipolytic activity of remaining isolates varied in the range from $61.4 \pm 0.0$ to $470.7 \pm 0.0 \mathrm{mmol} / \mathrm{h} / \mathrm{mg}$ of protein. In general, enterococci isolated from sausages showed higher lipolytic activity compared to rabbit enterococci; on the other hand, rabbit staphylococci produced more lipase than was measured in staphylococci from fermented meat products. The predominance of staphylococcal lipolytic activity of both origins was detected; the selected strains could be recommended as starter culture in sausage production, e.g. by improving meat quality due to their lipid content.
\end{abstract}

Bacteria, lipase, metabolic activity, rabbit, fermented meat products

At present, lipases (glycerol ester hydrolases, E.C. 3.1.1.3) form an important group of relevant enzymes and they find their use in a variety of biotechnological fields such as food and dairy, pharmaceutical, detergent, agrochemical, oleochemical, textile and cosmetic industries (Jaeger et al. 1994). Lipolytic enzymes are found in bacteria, plants as well as in animals (Saxena et al. 1999, 2003; Gupta et al. 2004). Lipases of microbial origin, mainly bacterial and fungal, find a wide use due to their manifold properties, easy extraction and unlimited supply as well as easy cultivation of microbes. Bacteria produce different classes of lipolytic enzymes, which are mostly extracellular; some of them have affinity to short-chain fatty acids, some have preference for unsaturated fatty acids and many others are non-specific (Saxena et al. 1999). Their activity is greatly influenced by biochemical and physico-chemical factors such as temperature, $\mathrm{pH}$, presence of lipids, inorganic salts, nitrogen and carbon sources (Jaeger et al. 1994; Gupta et al. 2004). There are many reviews and studies of the origin, production, biochemical and molecular properties as well as purification of bacterial lipolytic enzymes (Jaeger et al. 1994; Arpigny and Jaeger 1999; Saxena et al. 2003; Gupta et al. 2004). Although many of lipase-producing bacterial sources are available, only a few were characterized in detail and purified (Gupta et al. 2004). Of these, the lipases from Pseudomonas species are the most often and widely used in biotechnological processes (Jaeger et al. 1994). However, lipases produced by other bacterial genera, e.g. by Achromobacter, Alcaligenes, Arthrobacter, Bacillus, Burkholderia, Chromobacterium are also important (Gupta et al. 2004). Lipolytic activity is frequently detected among enterococci and staphylococci (Kar et al. 1996; Rosenstein and Götz 2000; El-Din et al. 2002); moreover, lipases from the genera Staphylococcus, Bacillus and Pseudomonas belong to the best studied enzymes (Arpigny and Jaeger 1999). The production of lipases is a general property

Address for correspondence:

M. Simonová

Institute of Animal Physiology

Slovak Academy of Sciences

Šoltésovej 4-6

04001 Košice, Slovakia

Phone: +421556336251

Fax: +421 557287842

E-mail: simonova@saske.sk

http://www.vfu.cz/acta-vet/actavet.htm 
mainly of staphylococci and enterococci, but also of other Gram-positive cocci, and plays a role in the flavour development of fermented meat products (Nychas and Arkoudelos 1990) and in cheese-making (Tsakalidou et al. 1993). For this reason staphylococci and enterococci are studied for their lipolytic ability.

The aim of this study was to examine the ability to produce lipolytic enzymes by staphylococci and enterococci from rabbit faeces and traditional fermented meat products selected as potential additives and/or probiotics in our laboratory (Laboratory of Animal Microbiology, Institute of Animal Physiology, Slovak Academy of Sciences in Košice, Slovakia), for their possible utilization as starter cultures in sausage production and as feed additives in rabbitries to maintain the rabbit meat quality (especially its lipid content).

\section{Materials and Methods}

Enterococci and staphylococci used in this study were isolated from the faeces of rabbits and Slovak traditional fermented meat products. They have previously been characterized to be potential probiotics (Lauková et al. 2004; Simonová et al. 2005, 2006; Strompfová et al. 2005). Enterococci and staphylococci were isolated from the faeces of 23 rabbits of different age (in the range from 2 months to 3 years) of 5 different rabbit flocks. Faeces were collected individually from each animal and treated by the standard microbiological dilution method using appropriate dilutions in $(0.85 \%)$ saline solution. The strains of enterococci and staphylococci isolated from 4 traditional Slovak meat products - sausages ( 2 of them were prepared using starter cultures) were selected by standard microbiological methods using appropriate dilutions in Buffered Peptone Water (Biomark, India). The samples were plated on M-Enterococcus agar and Mannitol Salt agar (Becton \& Dickinson, Cockeysville, USA; NF $\mathrm{V}$ 04-503, ISO 15214) and incubated at $37^{\circ} \mathrm{C}$ for $24-48 \mathrm{~h}$. Then the colonies were randomly picked up from each sample to have a target of 58 enterococcal colonies and 25 staphylococcal colonies from rabbits and 101 colonies of enterococci and 187 colonies of staphylococci from sausages, they were checked for purity and maintained on ME and MSA agar. DNA from each strain was obtained by a simple procedure: 1 loopful of bacterial colony $(10 \mu \mathrm{l})$ resuspended in $30 \mu \mathrm{l} \mathrm{H}_{2} \mathrm{O}$ and vortexed for $10 \mathrm{~min}$. Then the supernatant aliquots were used as template DNA. For the identification of enterococci, $10.0 \mu \mathrm{l}$ of the template were added to $39.5 \mu \mathrm{l}$ of the reagent mixture which contained $0.5 \mu \mathrm{M}$ each of primers, $0.2 \mathrm{mM}$ each deoxynucleotide (dATP, dTTP, dCTP, dGTP - dNTPs, Invitrogen), $2.5 \mathrm{mM} \mathrm{MgCl}_{2}$ (Invitrogen), $10 \times \mathrm{PCR}$ buffer (Invitrogen), $1.25 \mathrm{U}$ Taq polymerase (Invitrogen), and $\mathrm{H}_{2} \mathrm{O}$ to the total volume of $50 \mu \mathrm{l}$. The sequences of the primer pairs used for PCR-amplification of enterococci were as follows: for E. faecium 5'-GCAAGGCTTCTTAGAGA-3' and 5'-CATCGTGTAAGCTAACTTC-3' (Merck, Darmstadt, Germany), for E. faecalis 5'-ATCAAGTACAGTTAGTCTT-3' and 5'-ACGATTCAAAGCTAACTG-3' (Dutka-Malen et al. 1995; Woodford et al. 1997). For E. faecium and E. faecalis detection, the amplification protocol was as follows: initial denaturation at $95{ }^{\circ} \mathrm{C}$ for $2 \mathrm{~min}, 40$ cycles of $95{ }^{\circ} \mathrm{C}$ for $1 \mathrm{~min}, 55^{\circ} \mathrm{C}$ for 1 min, $72{ }^{\circ} \mathrm{C}$ for $1 \mathrm{~min}, 72^{\circ} \mathrm{C}$ for $10 \mathrm{~min}$. Techgene KRD thermocycler (Techne, UK) was used for all samples. The sequences of the primer pairs used for PCR-amplification of staphylococci were as follows: for $S$. xylosus 5'-AAGTCGGTTGAAAACCTAAA-3' and 5'-CATTGACATATTGTATTCAG-3', for S. carnosus 5'-GAACCGCATGGTTCTGCAA-3' and 5'-CGTCAAGGTGCGCATAGT-3'(Aymerich et al. 2003). In the case of staphylococci, $1.0 \mu \mathrm{l}$ of the template was added to $24 \mu \mathrm{l}$ of the reagent mixture which contained $0.5 \mu \mathrm{M}$ of each primer, $0.2 \mathrm{mM}$ of each deoxynucleotide (dATP, dTTP, dCTP, dGTP - dNTPs, Invitrogen), $2.5 \mathrm{mM} \mathrm{MgCl}_{2}$ (Invitrogen), $10 \times$ PCR buffer (Invitrogen), $1.25 \mathrm{U}$ Taq polymerase (Invitrogen), and water to a total volume of $25 \mu$. The amplification protocol was as follows: initial denaturation at $96^{\circ} \mathrm{C}$ for $3 \mathrm{~min}, 35$ cycles of $95^{\circ} \mathrm{C}$ for $30 \mathrm{~s}, 58^{\circ} \mathrm{C}$ for $30 \mathrm{~s}, 72^{\circ} \mathrm{C}$ for $30 \mathrm{~s}, 72^{\circ} \mathrm{C}$ for $5 \mathrm{~min}$. A Techgene KRD thermocycler (Techne, UK) was used for all samples. The PCR products $(10 \mu \mathrm{l}$ of each) were separated by electrophoresis in $0.8 \%$ agarose gels (SIGMA, Germany) buffered with $1 \times$ TAE (Merck, Germany) containing $1 \mu \mathrm{g} / \mathrm{ml}$ ethidium bromide (SIGMA, Germany). The molecular mass standard (100 bp DNA Ladder, Invitrogen) was used according to the manufacturer's instructions.

The strains for lipolytic activity test (Table 1) were propagated in Brain Heart Infusion broth (BHI, Oxoid, Basingstoke, England) for $18 \mathrm{~h}$ at $37^{\circ} \mathrm{C}$. The $18 \mathrm{~h}$ culture of each strain $(200 \mathrm{ml})$ was centrifuged $(4000 \mathrm{~g}, 40$ min; Centrifuge K23). The cell pellet - sediment was resuspended in $5 \mathrm{ml}$ of supernatant and disrupted using a Sonificator VC601 (Sonics \& Materials Inc., Newtown, USA; $7.5 \mathrm{~min} 2 \times 1 \mathrm{sec}, 80-100 \mathrm{mV}$ ) in an ice bath. The disrupted cells were centrifuged at $16000 \mathrm{~g}$ for $40 \mathrm{~min}$ and the supernatant was used as sample for lipase activity measurement - for incubation with tributyrin as well as for control samples (without tributyrin and incubation).

Activity of lipase was measured by the modified method of Bier (1955). Bacterial cultures $(0.4 \mathrm{ml})$ were incubated with Sörensen phosphate buffer $(\mathrm{pH} 6.0 ; 1.6 \mathrm{ml})$, containing $0.2 \mathrm{M} \mathrm{Na}_{2} \mathrm{HPO}_{4} .7 \mathrm{H}_{2} \mathrm{O}(0.88 \mathrm{ml})$ and 0.2 $\mathrm{M} \mathrm{Na}_{2} \mathrm{HPO}_{4}(0.12 \mathrm{ml})$ and emulsified using $150 \mathrm{mM}$ tributyrin $(2.0 \mathrm{ml})$. The emulsion (prepared from $10 \mathrm{ml}$ of tributyrin, Biochemica, Fluka, Switzerland; $1 \mathrm{ml}$ of Tween 80 , Biochemica and $100 \mathrm{ml}$ of destilled water) was disrupted using a Sonificator VC601 (Sonics \& Materials Inc.; $7.5 \mathrm{~min} 2 \times 1 \mathrm{sec}, 80-100 \mathrm{mV}$ ). The reaction 
mixture (bacterial culture, buffer and emulsion) was incubated $1 \mathrm{~h}$ at $39^{\circ} \mathrm{C}$ and then frozen. Control samples (bacterial culture, buffer) of each tested bacteria were prepared and treated as was described above, however, emulsified tributyrin was not added and the sample was not incubated; these samples were frozen immediately. The measurement of lipolytic activity of tested bacteria was conducted in five replicates of each.

Both samples, $3 \mathrm{ml}$ of each control and reaction, were determined by titration with $\mathrm{KOH}(0.2 \mathrm{M})$, using 7-8 drops of bromthymol blue solution as indicator (Dilutor apparatus), after steam distillation in the Markham apparatus (with $4 \mathrm{ml}$ of mixture $2.0 \mathrm{M} \mathrm{H}_{2} \mathrm{SO}_{4}$ and $40 \% \mathrm{MgSO}_{4}$ ). The blank sample was also prepared with $3 \mathrm{ml}$ of distilled water instead of sample.

Values of lipolytic activity were calculated using the following equation:

Lipolytic activity $=F \cdot\left[\left(\mathrm{V}_{\mathrm{R}}-\mathrm{V}_{\mathrm{B}}\right)-\left(\mathrm{V}_{\mathrm{C}}-\mathrm{V}_{\mathrm{B}}\right)\right] /$ Bacterial protein content,

where $F$ is a constant value $(333.33) / 2 . \mathrm{V}_{\mathrm{B}} ; \mathrm{V}_{\mathrm{R}} / \mathrm{V}_{\mathrm{C}}$ is $\mathrm{ml}$ of $\mathrm{KOH}$ used for titration of reaction/control sample; $\mathrm{V}_{\mathrm{B}}$ is $\mathrm{ml}$ of $\mathrm{KOH}$ used for titration of blank. The protein content $(\mathrm{mg} / \mathrm{ml})$ of tested bacteria was measured according to Bradford (1976). The lipolytic activity of tested bacterial strains was expressed in units $\mathrm{mmol} / \mathrm{h} / \mathrm{mg}$ of protein.

\section{Results and Discussion}

Among 58 enterococci isolated from rabbit faeces specified by PCR, 31 strains $(53.4 \%)$ were allotted to the species E. faecium and 11 strains (19.0\%) belonged to the species $E$. faecalis (Simonová et al. 2005). Concerning the rabbit staphylococci, 6 strains $(24.0 \%)$ were allotted to the species $S$. xylosus; the remained strains of staphylococci were not identified as $S$. xylosus or $S$. carnosus. The species of E. faecium dominated in sausages (69.3\%; 70 strains), whereas E. faecalis was identified in lower counts (8.9\%; 9 strains). On the other hand, E. faecalis was the dominating species among enterococci isolated from the traditional Portugal fermented product "chourico" (Lauková et al. 2007). Among 187 staphylococcal isolates from sausages, $63.6 \%$ of strains (119 isolates) were allotted to the species $S$. xylosus, $10.7 \%$ of strains (20 isolates) belonged to the species $S$. carnosus and $25.7 \%$ of isolates (48) were not identified. The species mentioned are frequently detected in fermented products (Simonová et al. 2004).

The target of strains included 6 strains of Enterococcus faecium from rabbit faeces, 1 strain of E. faecalis, 1 strain of Enterococcus sp., 1 strain of Staphylococcus xylosus and 5 strains of Staphylococcus sp. from rabbit faeces as well as 3 E. faecium strains from sausages, 2 strains of $S$. xylosus and 1 strain of $S$. carnosus isolated from the traditional Slovak sausage (Table 1) were selected to test their lipolytic activity developing on our previous studies concerning their properties (Lauková et al. 2004; Simonová et al. 2005, 2006; Strompfová et al. 2005).

Seven strains (4 rabbits enterococci, 2 rabbit staphylococci and 1 S. xylosus SX $\mathrm{SO} 1 / 1 \mathrm{M} / 1^{\prime} / 2$ strain- sausage isolate) were lipolytic activity free, whereas the lipolytic activity of other tested isolates varied in the range from $61.4 \pm 0.0$ to $470.7 \pm 0.0 \mathrm{mmol} / \mathrm{h} /$ $\mathrm{mg}$ of protein. In general, enterococci isolated from sausages showed higher lipolytic activity comparing to rabbit enterococci; on the other hand, rabbit staphylococci produced more lipase than measured in staphylococci from fermented meat products. Although the activity of lipolytic enzymes in the digestive tract of rabbits had been already measured by several authors (Marounek et al. 1995), information on the lipolytic activity of enterococci and staphylococci isolated from the rabbit ecosystem - digestive tract and faeces - has not yet been described. Enterococci of rabbit origin were able to degrade tributyrin; it might be interesting to monitor this property in connection with lipid metabolism and/or with the lipid content in rabbit meat. The detection of lipolytic activity among enterococci of dairy and meat (sausage) origin is more common and measured in higher values. El-Din et al. (2002) also described lipolytic enterococci isolated from dairy products using several natural and synthetic substrates, including tributyrin; enterococcal lipases hydrolysed tributyrin more rapidly than other simple triglycerides. On the other hand, measurements of the lipolytic activity of bacteria isolated from dairy and meat products are common and even requested because of the product quality. Moreover, lipolysis as technologically 
Table 1. Lipolytic activity of enterococci and staphylococci from rabbit faeces and traditional meat products

\begin{tabular}{|c|c|c|}
\hline Isolates & Source & $\begin{array}{c}\text { Lipolytic activity } \\
\text { (mmol/hour/mg of protein) }\end{array}$ \\
\hline E. faecium EF2019 & rabbit faeces & $199.3 \pm 109.0$ \\
\hline E. faecium EF1819 & rabbit faeces & $185.8 \pm 0.0$ \\
\hline E. faecium EF2119 & rabbit faeces & $75.9 \pm 0.0$ \\
\hline E. faecium EF1839 & rabbit faeces & 0 \\
\hline E. faecium EF529 & rabbit faeces & 0 \\
\hline E. faecium $\mathrm{EF} 24 / 10$ & rabbit faeces & 0 \\
\hline E. faecalis EE259 & rabbit faeces & $320.9 \pm 0.0$ \\
\hline E. sp. E829 & rabbit faeces & 0 \\
\hline S. xylosus SX519 & rabbit faeces & $470.7 \pm 0.0$ \\
\hline S. sp. S729 & rabbit faeces & $117.7 \pm 50.9$ \\
\hline S. sp. S1519 & rabbit faeces & $176.5 \pm 83.2$ \\
\hline S. sp. S239 & rabbit faeces & $160.5 \pm 87.8$ \\
\hline S. sp. S1629 & rabbit faeces & 0 \\
\hline S. sp. S1639 & rabbit faeces & 0 \\
\hline E. faecium $\mathrm{EF} \mathrm{SO} / \mathrm{F} 11$ & sausage & $441.3 \pm 176.5$ \\
\hline E. faecium $\mathrm{EF} \mathrm{SO} 2 / 223$ & sausage & $121.7 \pm 0.0$ \\
\hline E. faecium $\mathrm{EF} \mathrm{SO} 4 / 1 \mathrm{M} / 2$ & sausage & $356.6 \pm 123.5$ \\
\hline S. xylosus SX SO1/1M/1`/2 & sausage & 0 \\
\hline S. xylosus SX SO1/1M/2`/3 & sausage & $70.5 \pm 21.5$ \\
\hline S. carnosus $\mathrm{SC}$ SO2/F/2/5 & sausage & $61.4 \pm 0.0$ \\
\hline
\end{tabular}

E. - Enterococcus, S. - Staphylococcus, sp. - species

relevant property is usually determined to evaluate the strain suitability - mainly in the case of staphylococci - as starter culture in sausage fermentation, due to their contribution to the flavour development. Martin et al. (2006) described low lipolytic activities only in half of the staphylococci isolated from fermented sausages, whereas the species of $S$. xylosus was found in the highest percentage of lipolytic strains; it is in accordance with our results. Talon and Montel (1997) reported greater variety $(10.13-1502.85 \mathrm{nmol} / \mathrm{min} /$ $\mathrm{mg}$ of protein) of the butyrate hydrolyse activity of the extracellular extracts of different staphylococcal species, including $S$. carnosus, S. xylosus, S. warneri and S. saprophyticus, comparing to our results $(61.4-470.7 \mathrm{mmol} / \mathrm{h} / \mathrm{mg}$ of protein). Staphylococci of rabbit origin and also from fermented sausages were able to degrade tributyrin.

It can be concluded that enterococci and staphylococci isolated from the rabbit ecosystem and from fermented meat sausages are able to degrade tributyrin under laboratory conditions. From basic research point of view we would also like to compare the metabolic properties of the isolates from the genera Enterococcus and Staphylococcus or species of these genera from different sources to enrich and update already known data; it is a part of the longterm study. Predominance of the staphylococcal lipolytic activity of both sources, food and animal, was detected; the selected strains could be recommended as further starter culture in sausage production, e.g. by improving meat quality due to its lipid content. Of course, more detailed studies of their lipolytic activity are requested.

\section{Lipolytická aktivita potenciálnych probiotických enterokokov a stafylokokov}

V prezentovanej práci bola sledovaná schopnost' enterokokov a stafylokokov produkovat' lipolytické enzýmy. Testované kmene boli genotypizáciou priradené ku druhu Enterococcus faecium (3 izoláty z trusu králikov) a 1 kmeň bol bližšie nešpecifikovaný Enterococcus sp. Dva kmene stafylokokov (z trusu králikov) a kmeň Staphylococcus xylosus SX S0/1M/1'/2 
boli izolované z fermentovaných mäsových produktov. Tieto kmene nevykazovali lipolytickú aktivitu, zatial'čo lipolytická aktivita u ostatných testovaných kmeňov dosahovala hodnoty v rozsahu od $61.4 \pm 0.0$ do $470 \pm 0.0 \mathrm{mmol} / \mathrm{h} / \mathrm{mg}$ proteínu. Celkovo, enterokoky izolované Z fermentovaných mäsových produktov vykazovali vyššiu lipolytickú aktivitu v porovnaní s enterokokmi, ktoré boli izolované z trusu králikov; na druhej strane však stafylokoky izolované z králikov produkovali viac lipázy než stafylokoky z fermentovaných pruduktov. Avšak dominovala lipolytická aktivita u stafylokokov izolovaných z obidvoch ekosystémov. Niektoré z týchto kmeňov by mohli byt' využité ako štartérové kultúry pri výrobe fermentovaných mäsových produktov, pre lepšiu kvalitu mäsa v súvislosti s obsahom tukov v ňom.

\section{Acknowledgement}

This work was supported by the project VEGA 2/0008/28 and by international collaboration with the Institute of Animal Physiology and Genetics, Academy of Sciences of Czech Republic, Prague. The part of the results concerning the identification of rabbit enterococcal strains was already reported in Czech Journal of Animal Science (2005, 50: 416-421). We are grateful to Dr. Oxana Savka and Ing. Natalia Břeňová from the Laboratory of Physiology of Nutrition, Institute of Animal Physiology and Genetics, Academy of Sciences of Czech Republic in Prague for their skilful technical assistance.

\section{References}

ARPIGNY JL, JAEGER KE 1999: Bacterial lipolytic enzymes: classification and properties. Biochem J 343: $177-183$

AYMERICH T, MARTIN B, GARRIGA M, HUGAS M 2003: Microbial quality and direct PCR identification of lactic acid bacteria and nonpathogenic staphylococci from artisanal low-acid sausages. Appl Environ Microbiol 69: $4583-4594$

BIER M 1955: Lipases. In: COLOWICK SP, KAPLAN NO (Eds.): Methods in Enzymology. Academic Press, New York, pp. 627-642

BRADFORD MM 1976: A rapid and sensitive method for the quantitation of microgram quantities of protein utilizing the principle of protein-dye binding. Anal Biochem 72: 248-254

DUTKA-MALEN S, EVERS S, COURVALIN P 1995: Detection of glycopeptide resistance genotypes and identification to the species level of clinically relevant enterococci by PCR. J Clin Microbiol 33: 24-27

EL-DIN BB, EL-SODA M, EZZAT N 2002: Proteolytic, lipolytic and autolytic activities of enterococci strains isolated from Egyptian dairy products. Lait 82: 289-304

GUPTA R, GUPTA N, RATHI P 2004: Bacterial lipases: an overview of production, purification and biochemical properties. Appl Microbiol Biotechnol 64: 763-781

JAEGER KE, RANSAC S, DIJKSTRA BW, COLSON CH, VAN HEUVEL M, MISSET O 1994: Bacterial lipases. FEMS Microbiol Rev 15: 29-63

KAR M, RAY L, CHATTOPADHYAY P 1996: Isolation and identification of alkaline thermostable lipase producing microorganism and some properties of crude enzyme. Indian J Exp Biol 34: 535-538

LAUKOVÁ A, STROMPFOVÁ V, MARCIŇÁKOVÁ M, SIMONOVÁ M, HERICH R 2004: Occurrence of Enterococcus faecium in traditional fermented sausages. In: Proceedings of the $19^{\text {th }}$ international ICFMH symposium FoodMicro, 12-16 September. Portorož, Slovenia, pp. 352

LAUKOVÁ A, FRAQUEZA MJ, STROMPFOVÁ V, SIMONOVÁ M, ELIAS M, BARRETO A 2008: Bacteriocinogennic strains of Enterococcus faecalis isolated from chourico, traditional sausage produced in south Portugal. Folia Microbiol (Submitted)

MAROUNEK M, VOVK SJ, SKRIVANOVÁ V 1995: Distribution of activity of hydrolytic enzymes in the digestive tract of rabbits. Br J Nutr 73: 463-469

MARTIN B, GARRIGA M, HUGAS M, BOVER-CID S, VECIANA-NOGUÉS MT, AYMERICH T 2006: Molecular, technological and safety characterization of Gram-positive catalase-positive cocci from slightly fermented sausages. Int J Food Microbiol 107: 148-158

NYCHAS GJE, ARKOUDELOS JS 1990: Staphylococci: their role in fermented sausages. J Appl Bacteriol Symp (Suppl.) 69: 167S-188S

ROSENSTEIN R, GÖTZ F 2000: Staphylococcal lipases: biochemical and molecular characterization. Biochimie 82: $1005-1014$

SAXENA RK, GHOSH PK, GUPTA R, SHEBA DAVIDSON W, BRADOO S, GULATI R 1999: Microbial lipases: potential biocatalysts for the future industry. Curr Sci 77: 101-115

SAXENA RK, SHEORAN A, GIRI B, DAVIDSON WS 2003: Purification strategies for microbial lipases. J Microbiol Methods 52: 1-18

SIMONOVÁ M, STROMPFOVÁ V, MARCIŇÁKOVÁ M, LAUKOVÁ A, HERICH R 2004: Microflora detected in fermented meat processing. In: Proceedings of the International conference Agro-food legislation under the conditions of globalization, 29 September - 1 October. Štrbské Pleso, Slovakia, pp. 153-156 
SIMONOVÁ M, LAUKOVÁ A, ŠTYRIAK I 2005: Enterococci from rabbits - potential feed additive. Czech J Anim Sci 50: 416-421

SIMONOVÁ M, STROMPFOVÁ V, MARCIŇÁKOVÁ M, LAUKOVÁ A, VESTERLUND S, LATORRE MORATALLA M, BOVER-CID S, VIDAL-CAROU C 2006: Characterization of Staphylococcus xylosus and Staphylococcus carnosus isolated from Slovak meat products. Meat Sci 73: 559-564

STROMPFOVÁ V, SIMONOVÁ M, MARCIÑÁKOVÁ M, LAUKOVÁ A 2005: Bacteriocinogenic activity of selected lactic acid bacteria, isolates from Slovak meat products. In: Proceedings of the Hygiena alimentorum XXVI, 26 - 27 May. Štrbské Pleso, Slovakia, pp. 166-169

TALON R, MONTEL MC 1997: Hydrolysis of esters by staphylococci. Int J Food Microbiol 36: 207-214

TSAKALIDOU E, MANOLOPOULOU E, TSILIBARI V, GEORGALAKI M, KALANTZOPOULOS G 1993: Esterolytic activities from Enterococcus durans and Enterococcus faecium strains isolated from Greek cheese. Neth Milk Dairy J 47: 145-150

WOODFORD N, EGELTON MC, MORRISON D 1997: Comparison of PCR with phenotypic methods for the speciation of enterococci. Plenum Press New York 47: 405-409 